\title{
Studies on the Hematological Profile and Trace Elements in Oral Submucous Fibrosis
}

\author{
Cunnigaiper Dhanasekaran ANURADHA and \\ Chennam Srinivasulu Shyamala Devi* \\ Department of Biochemistry, University of Madras, \\ Guindy Campus, Madras-600 025, India
}

(Received February 2, 1995)

\begin{abstract}
Summary Oral submucous fibrosis is a chronic disease of obscure etiology affecting the oral cavity. Several histologic and epidemiologic studies on this condition have been conducted, but the biochemical aspects have not yet been thoroughly explored. Hence the present study was undertaken to study the hematological status and trace elements in this condition. There was no change in the cell count, whereas increases in platelet count, eosinophil number, and erythrocyte sedimentation rate were observed. There was a significant decrease in the levels of hemoglobin, iron, ceruloplasmin, copper and zinc; and they correlated well with the progression of the disease. Consideration of these findings should open new avenues for exploration of the disease from new perspectives.
\end{abstract}

Key Words: fibrosis, copper, zinc, ceruloplasmin, hemoglobin

Oral submucous fibrosis (OSMF) is an insidious disease affecting any part of the oral cavity and predominantly occurs among Indians [1], occasionally in other Asiatics, and sporadically in Europeans [2]. The early signs and symptoms are non-specific and are easily overlooked [3]. Patients with advanced disease seek attention because of progressive restricted mouth opening [4]. Certain clinical diagnostic criteria have been proposed, including oral mucosal blanching, which may be spotty, resulting in a marbled appearance, or a generalized opaque fibrotic appearance, and stiffness of the oral mucosa with trismus [5].

While the general consensus is that the disease is mostly seen in the second to fourth decades of life, Shiau and Kwan [6] reported the peak incidence to be between 30 and 50 years of age. Pindborg et al. [7] have reported an average age of incidence for men as 55 years and for women as 53.4 years.

* To whom correspondence should be addressed. 
OSMF affects all socioeconomic groups [8], and the etiology is still uncertain. Even though chillies, smoking [9], malnutrition [10], iron deficiency, vitamin deficiency, and autoimmunity [11] have been suggested, betel chewing has been repeatedly implicated in the etiology of OSMF $[12,13]$.

OSMF has been well established as a precancerous lesion. Most of the oral cancer patients had a preexisting mucosal lesion, mainly OSMF [14]. However, the percentage of patients with OSMF who may expect to develop malignancy is not clearly established since this percentage varies from 2 to 30\% [6]. The association between OSMF and carcinoma may depend upon the greater vulnerability of the thinned atrophic epithelium to carcinogens, which may at first stimulate epithelial atypia, later hyperplasia, and finally frank neoplasia [15].

Even though various studies have been carried out on the epidemiology and histology of OSMF $[10,12,16]$, very little information is available on the biochemical and clinical profile of these patients. Primary hematologic diseases are uncommon, whereas hematologic manifestations secondary to other diseases occur frequently. The hematologic status of a patient should be investigated thoroughly to evaluate the hematologic derangement, if any, that has occurred due to or in response to a primary disease [17]. Trace elements have been critically examined in the etiology of various diseases, especially cancer [18]. Hence we intended to study the hematological profile and trace elements in OSMF patients to get a better understanding of the disease from a new perspective.

\section{MATERIALS AND METHODS}

Subjects were selected from patients attending Madras Dental College and Saveetha Dental College, Madras, with any of the undermentioned signs and symptoms:

The diagnostic criteria of submucous fibrosis were

i) Burning sensation and difficulty in eating hot and spicy food.

ii) Blanched or opaque appearance of the mucosa.

iii) Presence of palpable fibrous bands.

iv) Atrophy of the tongue papillae.

v) Inability to open the mouth.

The patients were examined in adequate natural light by the examiner using two mouth mirrors and gloved fingers, and were classified into group II (early stage) group III (moderately advanced stage) and group IV (advanced stage) based on clinical criteria (Table 1) [19]. Group I subjects were normal volunteers attending the outpatient department for tooth extraction, and they were matched for age and sex. There were 22 patients in each group.

For biochemical investigation, blood was collected in clean tubes containing EDTA, and the plasma was used for the various estimations. In a separate tube, blood was collected and allowed to clot, then the serum was separated by centrifugation at $1,200 \times g$ for $5 \mathrm{~min}$. The plasma and serum were used for the enumera- 
Table 1. Clinical grading of severity.

\begin{tabular}{|c|c|c|}
\hline Group II & Group III & Group IV \\
\hline $\begin{array}{l}\text { Burning sensation and dry- } \\
\text { ness of mouth }\end{array}$ & $\begin{array}{l}\text { Burning sensation and dryness } \\
\text { of mouth }\end{array}$ & $\begin{array}{l}\text { Burning sensation and dryness } \\
\text { of mouth }\end{array}$ \\
\hline Irritation by spicy food & Irritation by spicy food & Irritation by spicy food \\
\hline $\begin{array}{l}\text { Oral mucosa is blanched and } \\
\text { loses its elasticity }\end{array}$ & $\begin{array}{l}\text { Blanched opaque, leather-like } \\
\text { mucosa }\end{array}$ & $\begin{array}{l}\text { Blanched opaque leather-like } \\
\text { mucosa }\end{array}$ \\
\hline No clearcut fibrotic bands & $\begin{array}{l}\text { Vertical fibrotic bands on buc- } \\
\text { cal mucosa making it stiff }\end{array}$ & $\begin{array}{l}\text { Thick fibrous bands occurring } \\
\text { in both buccal mucosa, in } \\
\text { retromolar area and at pter- } \\
\text { ygomandibular raphae }\end{array}$ \\
\hline $\begin{array}{l}\text { Slight restriction of mouth } \\
\text { opening }\end{array}$ & $\begin{array}{l}\text { Considerable restriction of } \\
\text { mouth opening }\end{array}$ & Very little mouth opening \\
\hline \multirow[t]{3}{*}{ Tongue protrusion normal } & $\begin{array}{l}\text { Tongue protrusion not much } \\
\text { affected }\end{array}$ & Restricted tongue protrusion \\
\hline & $\begin{array}{l}\text { Difficulty in eating and speak- } \\
\text { ing }\end{array}$ & $\begin{array}{l}\text { Speech and hearing very much } \\
\text { impaired }\end{array}$ \\
\hline & Oral hygiene poor & Oral hygiene very poor \\
\hline
\end{tabular}

tion of red blood corpuscles (RBC), white blood corpuscles (WBC), platelets, eosinophils, and for the determination of erythrocyte sedimentation rate (ESR) [20], hemoglobin [21], iron [22], plasma iron binding capacity (PIBC) [23], ceruloplasmin [24], and copper [25]. Zinc was measured with a Varian Techtron AA/475 atomic absorption spectrophotometer at a wavelength of $213.9 \mathrm{~nm}$ emitted by a zinc hollow cathode lamp.

Statistical analysis was done by Student's $t$-test.

\section{RESULTS}

Table 2 shows the red cell, white cell, platelet, and eosinophil counts and the ESR of OSMF patients and controls. There was no significant change in the RBC and $\mathrm{WBC}$ count in any stage of the disease between patients and controls. There was, however, a significant difference (decrease) in the platelet counts of group II $(p<0.001)$ and group III $(p<0.02)$ patients as compared with those of the controls. There was also a very high increase $(p<0.001)$ in the eosinophil count in all three groups of patients compared with the control group value. Likewise there was a marked increase $(p<0.001)$ in the ESR in all patient groups.

Table 3 depicts the levels of hemoglobin, packed cell volume, mean corpuscular volume (MCV), mean corpuscular hemoglobin $(\mathrm{MCH})$, and mean corpuscular hemoglobin concentration (MCHC). There was a tendency toward a decrease in the hemoglobin level in group II $(p<0.05)$ patients and a highly significant decrease $(p<0.001)$ in groups III and IV patients when their levels were compared to the control ones.

There was no significant change in hematocrit value between any patient group and the control. There was a significant decrease $(p<0.001)$ in the MCV in Vol. 19, No. 1, 1995 
Table 2. Red cell, white cell, platelet, and eosinophil counts, and ESR, in normal and OSMF patients.

\begin{tabular}{lcccc}
\hline & Group I & Group II & Group III & Group IV \\
\hline Red cell count $\left(\times 10^{6} / \mu\right.$ l blood $)$ & $5.37 \pm 1.1$ & $5.16 \pm 0.9^{\mathrm{NS}}$ & $5.89 \pm 1.1^{\mathrm{NS}}$ & $5.42 \pm 1.7^{\mathrm{NS}}$ \\
White cell count $\left(\times 10^{3} / \mu\right.$ l blood $)$ & $7.86 \pm 2.9$ & $6.29 \pm 2.5^{\mathrm{NS}}$ & $7.26 \pm 1.4^{\mathrm{NS}}$ & $8.02 \pm 1.6^{\mathrm{NS}}$ \\
Platelet count $\left(\times 10^{3} / \mu 1\right.$ blood $)$ & $301 \pm 26.4$ & $268 \pm 24.5^{* * *}$ & $274 \pm 22.7^{* *}$ & $311 \pm 29.6^{\mathrm{NS}}$ \\
Eosinophil $($ per cu.mm) & $350 \pm 28.9$ & $456 \pm 34.7^{* * *}$ & $579 \pm 23.5^{* * *}$ & $610 \pm 39.3^{* * *}$ \\
ESR $(\mathrm{mm} / \mathrm{h})$ & $2.6 \pm 0.4$ & $7.2 \pm 1.9^{* * *}$ & $20.1 \pm 2.4^{* * *}$ & $14 \pm 3.6^{* * *}$ \\
\hline
\end{tabular}

Values are expressed as the mean \pm SD for 22 patients in each group. Groups II, III, and IV were each compared with group I (normal individuals). ${ }^{\mathrm{NS}}$ Nonsignificant; ${ }^{* *} p<0.02 ;{ }^{* * *} p<$ 0.001 .

Table 3. Hemoglobin, hematocrit, MCV, MCH, and MCHC levels in normal and OSMF patients.

\begin{tabular}{lcccc}
\hline & Group I & Group II & Group III & Group IV \\
\hline Hemoglobin $(\mathrm{g} / \mathrm{dl})$ & $15.5 \pm 2.7$ & $13.92 \pm 1.6^{*}$ & $11.87 \pm 1.9^{* * *}$ & $13.4 \pm 1.9^{* * *}$ \\
Hematocrit $(\%)$ & $49.2 \pm 4.3$ & $41.7 \pm 3.9^{\mathrm{NS}}$ & $45.2 \pm 3.3^{\mathrm{NS}}$ & $49.1 \pm 4.7^{\mathrm{Ns}}$ \\
$\begin{array}{l}\text { Mean corpuscular volume } \\
\quad\left(\mu \mathrm{m}^{3} / \text { red cell) }\right.\end{array}$ & $91.6 \pm 5.3$ & $80.8 \pm 4.7^{* * *}$ & $76.7 \pm 3.6^{* * *}$ & $90.5 \pm 4.1^{\mathrm{NS}}$ \\
$\begin{array}{l}\text { Mean corpuscular hemoglobin } \\
\quad(\mathrm{pg} / \mathrm{RBC})\end{array}$ & $28.8 \pm 2.7$ & $26.9 \pm 2.3^{* *}$ & $20.15 \pm 1.96^{* * *}$ & $24.7 \pm 3.1^{* * *}$ \\
$\begin{array}{l}\text { Mean corpuscular hemoglobin } \\
\text { concentration }(\mathrm{g} / \mathrm{dl} \mathrm{RBC})\end{array}$ & $31.5 \pm 2.7$ & $33.3 \pm 2.6^{*}$ & $26.2 \pm 1.9^{* * *}$ & $27.2 \pm 2.1^{* * *}$ \\
\hline
\end{tabular}

Values are expressed as mean \pm SD for 22 patients in each group. Groups II, III, and IV were each compared with group I (normal individuals). NS Nonsignificant; ${ }^{*} p<0.05 ;{ }^{*} p<0.02$; ${ }^{* * *} p<0.001$.

Table 4. Levels of iron, iron binding capacity, ceruloplasmin, copper, and zinc in normal and OSMF patients.

\begin{tabular}{lrccc}
\hline & Group I & \multicolumn{1}{c}{ Group II } & \multicolumn{1}{c}{ Group III } & \multicolumn{1}{c}{ Group IV } \\
\hline Iron $(\mu \mathrm{mol} /$ liter $)$ & $24.3 \pm 2.7$ & $7.1 \pm 1.3^{* * *}$ & $6.3 \pm 1.2^{* * *}$ & $6.8 \pm 0.9^{* * *}$ \\
Iron binding capacity $(\mu \mathrm{mol} /$ liter $)$ & $46.7 \pm 3.8$ & $69.6 \pm 4.7^{* * *}$ & $72.4 \pm 9.2^{* * *}$ & $71.3 \pm 6.8^{* * *}$ \\
Ceruloplasmin $(\mu \mathrm{mol} /$ liter$)$ & $1.8 \pm 0.9$ & $0.97 \pm 0.8^{* *}$ & $0.90 \pm 0.7^{* *}$ & $1.02 \pm 0.9^{* *}$ \\
Copper $(\mu \mathrm{mol} /$ liter $)$ & $29.4 \pm 3.7$ & $13.9 \pm 1.9^{* * *}$ & $12.6 \pm 1.7^{* * *}$ & $14.3 \pm 2.3^{* * *}$ \\
Zinc $(\mu \mathrm{mol} /$ liter$)$ & $18.26 \pm 2.6$ & $14.73 \pm 2.3^{\mathrm{NS}}$ & $7.21 \pm 1.1^{* * *}$ & $6.58 \pm 1.4^{* * *}$ \\
\hline
\end{tabular}

Values are expressed as the mean \pm SD for 22 patients in each group. Groups II, III, and IV were each compared with group I (normal individuals). NS Nonsignificant; ${ }^{* *} p<0.02$; $* * * p<0.001$.

groups II and III patients and a significant decrease $(p<0.001)$ in the $\mathrm{MCH}$ level in all three groups as compared with the control value. The MCHC showed a significant decrease $(p<0.05)$ in group II, and a highly significant decrease $(p<$ 0.001 ) was observed in groups III and IV.

Table 4 gives the levels of iron, iron binding capacity, ceruloplasmin, copper, and zinc. There was a highly significant decrease $(p<0.001)$ in the serum iron level in all of the patient groups and a corresponding increase $(p<0.001)$ in the iron 
binding capacity in the serum of all the patients.

Ceruloplasmin and copper showed a significant decrease $(p<0.02$ and $p<$ 0.001 , respectively) in all the patients. The zinc level was found to be decreased $(p<0.001)$ in groups III and IV when compared with the control value.

\section{DISCUSSION}

Examination of the blood is performed in almost all patients with illness because of the importance of determining alterations in it, if any. Other abnormalities may also be detected in blood by either quantitative or qualitative studies.

The findings on normal red cell count and white cell count agree with those of earlier studies [26]. There was a nonspecific increase in the platelet level in groups II and III patients, but they were within the normal physiological range.

The increased level of eosinophils seen may be due to inflammatory reactions, which are evident in OSMF patients. OSMF is known to occur in individuals with hypersensitivity to allergens present in the betelnut [27]. Since all OSMF patients were habitual chewers of this nut, this hypersensitivity explains the increase in eosinophil levels. The eosinophil was shown to be increased in carcinomatosis [28-30], and marked eosinophilia had been reported in almost all OSMF cases studied. All OSMF patients in our study had a marked increase in their ESR. A similar finding was made over a decade ago [31]. However, OSMF cases with a normal ESR have also been reported [32].

A significant decrease in the hemoglobin concentration suggests iron deficiency. A hemoglobin estimation of $45 \%$ in OSMF patients was reported earlier [31]. However, Moos and Madan [32] reported normal Hb levels in the two cases studied by them. Rajendran et al. [33] reported a significant depression in hemoglobin levels in 50 OSMF cases studied. A study conducted by Sen and Banerjee [34] reported lower hemoglobin levels in subjects with cancer of various types.

The hematocrit of OSMF patients was normal. The hematocrit is the portion of blood occupied by erythrocytes [35] and since the red cell count is normal in these patients, it explains the normal hematocrit value. However, the MCV was significantly decreased in groups II and III patients. This decrease in MCV suggests microcytic anemia. Seventy percent of iron deficiency anemia cases are reported to display microcytosis [36].

As the degree of iron deficiency increases, the hemoglobin concentration decreases further; and microcytosis and hypochromia then appear. The changes in erythrocyte volume and hemoglobin that accompany severe iron deficiency are expressed quantitatively as erythrocyte corpuscular indices [37].

The $\mathrm{MCH}$ decreased significantly in all the patients, thus indicating hypochromic anemia. This is due to the decreased hemoglobin content of a single red cell since $\mathrm{MCH}$ is the hemoglobin content of a single red cell. Patients in group II had a slightly elevated MCHC level, whereas patients in groups III and IV had 
low MCHC levels. However, MCHC levels are known to decrease only in advanced cases of iron-deficiency anemia and are normal in most cases of the early iron deficiency [38-40]. Iron-deficiency anemia in OSMF patients was reported earlier [41]. A parallel can be drawn between OSMF and Plummer Vinson syndrome, for in the latter the buccal mucosa shows thinning and keratinization of epithelium and increased mitotic activity, which are changes secondary to longstanding iron deficiency [42, 43].

The marked decrease in the serum iron level led to iron-deficiency anemia in OSMF patients. Decreased levels of serum iron in other OSMF patients were reported earlier [33]. Our study of OSMF patients comprised both moderate cases and advanced cases of iron deficiency. Such deficiency is most often a result of unsupplemented milk diets, inadequate dietary iron intake, and malabsorption of iron. The patients were following poor dietary patterns, and many of them complained of a loss of appetite. Their food intake was also considerably reduced due to both their inability to open their mouth and ulcerations.

Disturbances in cellular metabolism and function may occur in many tissues in iron deficiency $[44,45]$. Achlorhydria has been found in as many as $43 \%$ of patients with iron deficiency $[46,47]$, and many cases of OSMF with achlorhydria have been reported [48].

The iron binding capacity in serum had increased in OSMF patients. A similar finding was previously reported [33]. IBC is the measure of the amount of transferrin in the circulating blood. Transferrin is normally 20 to $50 \%$ saturated with iron. A transferrin saturation of $15 \%$ or less is often found in iron-deficiency anemia [8].

The decreased levels of copper is of great significance in the etiology of OSMF. The decrease in copper levels obviously brings about a decrease in ceruloplasmin levels. Copper influences iron absorption and mobilization of iron from the liver and other tissue stores [49]. Thus a deficiency in copper will also affect iron absorption and thus may explain iron deficiency.

The copper-containing enzyme lysyl oxidase is involved in the oxidation of the $\varepsilon$-amino group of lysine to an aldehyde group that then reacts with another lysine to form desmosine, the cross linking group of collagen [50]. OSMF has been established as a collagen disorder [51] in which there is extensive collagen synthesis, which might, in turn, deplete copper levels due to the utilization of this metal ion in the process.

The zinc level was also found to be decreased in our studies. An alteration in serum zinc and copper levels in sarcoma patients was reported [52]. Abdulla et al. [53] reported a decrease in blood zinc and copper in the sera of patients with oral cancer. In contrast, Vyas et al. [54] reported an elevation in the serum zinc and copper levels in malignancy. Zinc deficiency was correlated with high occurrences of premalignant and malignant lesions of the esophagus [55]. Structural changes in the oral epithelium in zinc deficiency was observed by Charles et al. [56]. A decreased level of serum zinc is associated with carcinogenesis $[57,58]$. This may 
be due to the increased utilization of zinc by tumor tissues; however the reason for the decrease in serum zinc is not known [59]. Recent studies prove a beneficial role of oral zinc in the therapy of OSMF [60]. The importance of these results is that the causation and cure of premalignant lesions now lack a scientific basis. The result it is hoped would open new avenues for a better understanding of the disease.

We thank Professor Dr. C.K. Dhanasekaran of Saveetha Dental College, Madras, and Professor Dr. N. Gnanasundaram of Madras Dental College for providing the samples. The financial grant from Hindustan Ciba Geigy and the Council for Scientific and Industrial Research is greatly acknowledged.

\section{REFERENCES}

1. Pindborg, J.J., Murti, P.R., Bhonsle, R.B., Gupta, P.C., Daftary, D.K., and Mehta, F.S. (1984): Oral submucous fibrosis as a precancerous condition. Scand. J. Dent. Res., 92, 224229.

2. Lemmer, J., and Shear, M. (1967): Oral submucous fibrosis. A possible case in a person of Caucasian descent. Br. Dent. J., 122, 343-346.

3. Dudani, I.C., and Kher, M.M. (1971): Oral submucous fibrosis. J. Indian Med. Assoc., 57, 347-348.

4. Rao, A.B. (1962): Idiopathic palatal fibrosis. Br. J. Surg., 50, 23-25.

5. Mc. Gurk, M., and Craig, C.T. (1984): Oral submucous fibrosis: Two cases of malignant transformation in Asian immigrants to the United Kingdom. Br. J. Oral Maxillofac. Surg., 22, 56-64.

6. Shiau, Y.Y., and Kwan, H.K. (1979): Submucous fibrosis in Taiwan. Oral Surg. Oral Med. Oral Pathol., 47, 453-457.

7. Pindborg, J.J., Hemming, P.E., and Zachariah, J. (1967): Oral epithelial changes in thirty Indians with oral cancer and submucous fibrosis. Cancer, 20, 1141-1146.

8. Pindborg, J.J., Chawla, T.N., Srivatsava, A.N., Gupta, D., and Mehrotra, M.L. (1964): Clinical aspects of oral submucous fibrosis. Acta Odont. Scand., 22, 679-691.

9. Wahi, P.N., Kapur, V.L., Luthra, U.K., and Srivatsava, M.C. (1966): Submucous fibrosis of the oral cavity. Bull. W.H.O., 35, 789-792.

10. Wahi, P.N., Kapur, V.L., Luthra, U.K., and Srivatsava, M.C. (1966): Submucous fibrosis of the oral cavity: Studies on epidemiology. Bull. W.H.O., 65, 793-799.

11. Caniff, J.P., Batchelor, J.R., Dodi, I.A., and Harvey, W. (1985): Major histocompatibility complex typing in oral submucous fibrosis. Tissue Antigens, 26, 138-142.

12. Mehta, F.S., Gupta, P.C., Daftary, D.K., Pindborg, J.J., and Choksi, S.K. (1972): An epidemiologic study of oral cancer and precancerous conditions among 101, 761 villagers in Maharashtra, India. Int. J. Cancer, 10, 134-141.

13. Gupta, D.S., Gupta, M.K., and Golhar, B.L. (1980): Oral submucous fibrosis-Clinical study and management by physiofibrolysis. J. Indian Dent. Assoc., 52, 375-378.

14. Prabha, B., Pillai, M.R., and Abraham, T. (1987): Immunology of premalignant and malignant conditions of the oral cavity. J. Oral Pathol., 16, 389-391.

15. Duckworth, R. (1976): Non infectious diseases of the oral mucosa, in Scientific Foundation of Dentistry, ed. by Bertram, C., and Ivor, K., Pitman Press, London, pp. 458-468.

16. Mani, N.J., and Singh, B. (1976): Studies on oral submucous fibrosis. J. Oral Surg., 41, 203213.

17. Williams, J. (1983): Clinical evaluation of the patient, in Hematology, ed. by McGraw, R.P., and Lerner, M., McGraw Hill, Singapore, pp. 3-9.

18. Sullivan, J.F., Blotcky, A.J., Williams, R., and Burch, R.E. (1978): Serum selenium and

Vol. 19, No. 1, 1995 
other trace elements in various diseases. Clin. Res., 26, 586-594.

19. Jain, P., and Suman, V.K. (1988): Oral submucous fibrosis-A new approach towards its management. J. Indian Dent. Assoc., 60, 38-46.

20. Raghuramulu, N., Madhavan, K., and Kalyana Sundaram, S. (1983): Haematological techniques, in A Manual of Laboratory Techniques, Silver Prints, India, pp. 254-258.

21. Van Kampen, H., and Zijlstra, M. (1961): Estimation of hemoglobin in blood. Clin. Chim. Acta, 6, 538-543.

22. Ramsay, W.N.M. (1953): Determination of iron in blood plasma or serum. Biochem. J., 53, $227-231$.

23. Ramsay, W.N.M. (1958): Advances in Clinical Chemistry, ed. by Sobotka, H., and Stewart, C.P., Academic Press, New York, pp. 1-14.

24. Ravin, H.A. (1961): Improved colorimetric enzymic assay of ceruloplasmin. J. Lab. Clin. Med., 58, 161-168.

25. Eden, A., and Green, A. (1940): Micro determination of copper in biological material. Biochem. J., 34, 1202-1208.

26. Hammer, J.E., Looney, P.D., Chused, T.M., and Bethseda, M.D. (1974): Submucous fibrosis. Oral Surg., 37, 412-421.

27. Sirsat, S.M., and Khanolkar, V.R. (1960): Submucous fibrosis of the palate in diet-preconditioned Wistar rats. Arch. Pathol., 70, 171-179.

28. Fahey, R.H. (1951): Unusual leukocyte responses in primary carcinoma of the lung. Cancer, 4, 930-936.

29. Reed, R.J., and Terasaki, N. (1972): Subcutaneous angioplastic lymphoid hyperplasia with eosinophilia. Cancer, 29, 489-493.

30. Wasserman, S.I., Goetzl, J., Ellman, L., and Austen, K.F. (1974): Tumor associated eosinophilotactic factor. N. Engl. J. Med., 290, 420-429.

31. Gupta, P.C., Mehta, F.S., and Daftary, D.K. (1980): Incidence rates of oral cancer and natural history of oral precancerous lesions in a 10 years follow up study of Indian villagers. Commun. Dent. Oral Epidemiol., 8, 287-333.

32. Moos, K.F., and Madan, D.K. (1968): Submucous fibrosis. Br. Dent. J., 124, 313-317.

33. Rajendran, R., Vasudevan, D.M., and Vijayakumar, T. (1990): Serum levels of iron and proteins in oral submucous fibrosis. Ann. Dent., 49, 23-25.

34. Sen, R., and Banerjee, A.B. (1986): Hemoglobin levels in cancer patients. J. Indian Dietet. Assoc., 11, 28-31.

35. Wintrobe, M.M. (1933): Macroscopic examination of the blood. Am. J. Med. Sci., 185, 5864.

36. Beutler, E., and Fairbanks, V.F. (1980): The effects of iron deficiency, in Iron in Biochemistry and Medicine, ed. by Jacobs, A., and Worwood, M., Academic Press, New York, pp. 3641.

37. Williams, J. (1983): Erythrocyte disorders related to disturbances of hemoglobin synthesis, in Hematology, ed. by Mc Graw, R.P., and Lerner, M., McGraw Hill, Singapore, pp. 460488.

38. Fairbanks, V.F. (1971): Is the peripheral blood film reliable for the diagnosis of iron deficiency anaemia? Ann. J. Clin. Pathol., 55, 447-459.

39. England, J.M., Walford, D.M., and Water, D.A.W. (1972): Reassessment of the reliability of the hematocrit. Br. J. Haematol., 23, 247-256.

40. England, J.M., and Fraser, P.M. (1973): Differentiation of iron deficiency from thalassemia trait by routine blood count. Lancet, 1, 449-456.

41. Sirsat, S.M., and Khanolkar, V.R. (1962): Submucous fibrosis of the palate and pillar of the fauces. Indian J. Med. Sci., 16, 189-197.

42. Suzman, M.M. (1933): Syndrome of anemia, glossitis, and dysphagia: Report of eight cases, with special reference to observations at autopsy in one instance. Arch. Intern. Med., 51, 17.

43. Vinson, P.P. (1922): Hysterical dyphagia. Minn. Med., 5, 107-114. 
44. Shearman, D.J.C., Delamore, I.W., and Gardner, D.L. (1966): Gastric function and structure in iron deficiency. Lancet, 1, 845-852.

45. Dagg, J.H., Goldberg, A., Gibbs, W.N., and Anderson, J.R. (1966): Detection of latent pernicious anaemia in iron deficiency anaemia. Br. Med. J., 2, 619-623.

46. Jacobs, A., Lawrie, J.H., Entwistle, C.C., and Campbell, H. (1966): Gastric acid reaction in chronic iron-deficiency anemia. Lancet, 2, 190-197.

47. Stone, W.D. (1968): Gastric secretory response to iron therapy. Gut, 9, 99-106.

48. Paymaster, J.C. (1956): Cancer of the buccal mucosa-A clinical study of 650 cases in Indian patients. Cancer, 9, 431-435.

49. Swaminathan, M. (1981): Minerals, in Biochemistry for Medical Students, Geetha Book House, India, pp. 358-410.

50. Eyre, D.R. (1984): Quantitation of hydroexy pyridinium cross links in collagen by high-performance liquid chromatography. Ann. Rev. Biochem., 53, 717-736.

51. Yen, D.J.C. (1982): Surgical treatment of submucous fibrosis. Oral Surg., 54, 269-272.

52. Fischer, G.L., Byers, V.S., Shifrine, M., and Lewin, A.S. (1973): Copper and zinc levels in serum from human patients with sarcomas. Cancer, 37, 356-363.

53. Abdulla, M., Biokernal, A., Mathur, A., and Wallenues, K. (1978): Zinc and copper levels in whole blood and plasma from patients with squamous cell carcinoma of head and neck, in The Role of Zinc in Experimental and Human Cancer, Univ. of Lund Publishers, Lund, pp. 36-39.

54. Vyas, R.K., Gupta, A.P., Gupta, A., and Aeross, A.K. (1982): Serum copper, zinc, magnesium and calcium level in various human diseases. Indian J. Med. Res., 76, 301-304.

55. Khojasteh, A., and Kraybill, W.G. (1988): Cancer of the esophagus-The environmental connection. South. Med. J., 81, 878-882.

56. Charles, E.J., Ashrafi, S.H., and Waterhouse, J.G. (1981): Structural changes in rabbit oral epithelium caused by zinc deficiency. $J$. Nutr., 111, 53-57.

57. Addink, N.W.H., and Frank, L.J.P. (1959): Remarks apropos of analysis of trace elements in human tissues. Cancer, 12, 551-554.

58. Miles, D.A. (1982): Functions of zinc: A literature resume. J. Oral Med., 37, 95-97.

59. Fischer, P.W.F., L'Abbe, M.R., and Gerona, A. (1984): Effect of zinc supplementation on copper status in humans. Fed. Proc., 43, 23-29.

60. Kumar, A., Sharma, S.C., Sharma, D., Chandra, K.C., and Amit, N. (1991): Beneficial effect of oral zinc in the treatment of oral submucous fibrosis. Indian J. Pharmacol., 23, 236-241. 